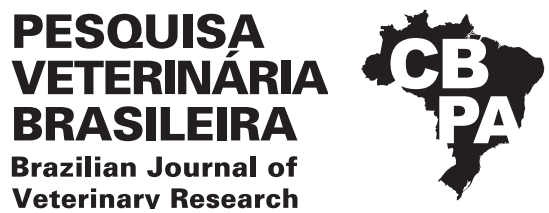

Pesq. Vet. Bras. 41:e06645, 2021

DOI: 10.1590/1678-5150-PVB-6645

Original Article

Livestock Diseases

ISSN 0100-736X (Print)

ISSN 1678-5150 (Online)

(cc) BY-NC

\title{
Expression of icaA and icaD genes in biofilm formation in Staphylococcus aureus isolates from bovine subclinical mastitis ${ }^{1}$
}

\begin{abstract}
Viviane F. Marques ${ }^{2}$, Huarrisson A. Santos ${ }^{2}$, Thomas H. Santos ${ }^{2}$, Dayanne A. Melo ${ }^{2 *}$ (D), Shana M.O. Coelho ${ }^{2}$, Irene S. Coelho ${ }^{2}$ and Miliane M.S. Souza ${ }^{2}$

ABSTRACT.- Marques V.F., Santos H.A., Santos T.H., Melo D.A., Coelho S.M.O., Coelho I.S. \& Souza M.M.S. 2021. Expression of icaA and icaD genes in biofilm formation in Staphylococcus aureus isolates from bovine subclinical mastitis. Pesquisa Veterinária Brasileira 41:e06645, 2021. Departamento de Microbiologia e Imunologia Veterinária, Universidade Federal Rural do Rio de Janeiro, BR-465 Km 7, Seropédica, RJ 23897-000, Brazil. E-mail: daymelo.com@gmail.com Staphylococcus spp. plays a significant role in the etiology of bovine mastitis. Staphylococcus aureus is considered the most important species due to the high prevalence and the difficulty of in vivo treatment that is related to the expression of virulence factors and biofilm formation. This study aimed to detect the phenotypic expression of the biofilm formation in 20 S. aureus isolated from bovine mastitis and to evaluate the expression and regulation of genes involved in its production. MALDI-TOF and phenogenotypic identification assays were performed to characterize the isolates. The phenotypic biofilm production and the presence of icaA and $i c a \mathrm{D}$ and bap genes were evaluated. The Agr system was typified (agr I, agr II, agr III and agr IV) and its regulator (agr RNAIII) was detected. Furtherly, Real-time PCR (qPCR) was performed at chosen times to quantify the expression of icaA, icaD and hld genes in three selected isolates. All 20 strains were biofilm producers and most presented icaA and icaD genes. Only one isolate presented the bap gene. The agr gene type II showed a prevalence of $70 \%$. Transcriptional analysis revealed increased expression of ica genes at eight hours of growth. These results confirm that polysaccharides production mediated by the icaADBC operon genes is an essential mechanism to the biofilm formation and contributes to the early stages of bacterial growth.
\end{abstract}

INDEX TERMS: Gene, biofilm, Staphylococcus aureus, bovine subclinical mastitis, bovine, icaA, icaD, hld, Agr types.

RESUMO.- [Expressão dos genes icaA e icaD na formação de biofilme em isolados de Staphylococcus aureus de mastite subclínica bovina.] Staphylococcus spp. desempenham um papel significativo na etiologia da mastite bovina. Staphylococcus aureus é considerada a espécie mais importante devido a alta prevalência e a dificuldade de tratamento in vivo que está relacionado à expressão dos fatores de virulência e formação de biofilme. Este estudo teve como objetivo detectar a expressão fenotípica da formação de biofilme em 20 cepas de $S$. aureus isoladas de mastite bovina e avaliar a expressão e regulação de genes envolvidos em sua produção. MALDI-TOF e ensaios de identificação fenogenotípica foram realizados para caracterizar os isolados. A produção fenotípica de biofilme

\footnotetext{
${ }^{1}$ Received on February 1, 2021.

Accepted for publication on March 16, 2021.

${ }^{2}$ Departamento de Microbiologia e Imunologia Veterinária, Universidade Federal Rural do Rio de Janeiro (UFRRJ), BR-465 Km 7, Seropédica, RJ 23897000, Brazil. *Corresponding author: daymelo.com@gmail.com
}

e a presença dos genes icaA, icaD e bap foram avaliadas. 0 sistema Agr foi tipificado (agr I, agr II, agr III e $a g r$ IV) e seu regulador (agr RNAIII) foi detectado. Além disso, a PCR em tempo real (qPCR) foi realizada nos tempos determinados para quantificar a expressão dos genes ica $\mathrm{A}$, icaD e hld em três isolados selecionados. Todas as 20 linhagens foram produtoras de biofilme e a maioria apresentava os genes icaA e icaD. Apenas um isolado apresentou o gene bap. 0 gene agr do tipo II mostrou uma prevalência de $70 \%$. A análise transcricional revelou aumento da expressão de genes ica às oito horas de crescimento. Estes resultados confirmam que a produção de polissacarídeos mediada pelos genes do operon icaADBC é um mecanismo essencial para a formação do biofilme e contribui para os estágios iniciais do crescimento bacteriano.

TERMOS DE INDEXAÇ̃̃O: Gene, biofilme, Staphylococcus aureus, mastite subclínica bovina, bovinos, icaA, icaD, hld, tipos de Agr. 


\section{INTRODUCTION}

Staphylococcus spp. have an essential role in the etiology of intramammary infections of dairy cattle. Of these, Staphylococcus aureus, stand out among the etiological agents prevalent in this type of infection. The adhesion of Staphylococcus spp. to the epithelium of the mammary gland is considered the first critical point in the pathogenesis of mastitis, and the ability to adhere and colonize the surface of the epithelium has been associated with the production of biofilms (Saei 2012). Although biofilms are generally composed of several bacterial species, those of staphylococcal origin are usually not heterogeneous (Arciola et al. 2012).

The formation of the biofilm is divided into four stages. The first one where non-specific interactions between the bacteria and the surface of the material are carried out by hydrophobic, electrostatic and Lifshitz-Van DerWaals forces. The second step, the formation of multiple bacterial layers, is an active process mediated by adhesins called MSCRAMMs (Microbial Surface Components Recognizing Adhesive Matrix Molecules) and by intercellular adhesion. In the subsequent third step, biofilm maturation and the development of specific structural characteristics according to the bacterial species occur. Bacterial detachment and dispersion characterize the fourth stage where the bacteria protected in the biofilm structure return to their original planktonic form and are ready for a new invasive phase (Arciola et al. 2012).

The biofilm formation is related to the production of an extracellular mucopolysaccharide, called "slime" composed of a high molecular weight polysaccharide, polysaccharide intercellular adhesin (PIA), which is a positively charged polymer of $\beta-1,6-\mathrm{N}$-acetylglucosamine residues, also known as PNAG. The intercellular adhesin (ica) operon formed by the $i c a \mathrm{~A}, i c a \mathrm{~B}, i c a \mathrm{C}$ and $i c a \mathrm{D}$ genes and the regulatory gene, ica $\mathrm{R}$, mediates the PNAG production. These genes encode ICAA, ICAB, ICAC and ICAD proteins involved in the synthesis of this polymer. ICAA is a trans-membrane glycosyltransferase and can synthesize short PNAG polymers in vitro using GDP$\mathrm{N}$-acetyl-glucosamine as a substrate. ICAD increases the efficiency of ICAA biosynthesis (Atkin et al. 2014).

From a clinical point of view, biofilms represent a critical issue since the aggregated bacteria exhibit high resistance to antimicrobial agents and the immune defense mechanisms of the host. Among the devices responsible for this resistance there is the physical diffusion barrier formed by the exopolissacaridic matrix, which hinders the penetration of the antimicrobial (Coelho et al. 2011, Arciola et al. 2012).

Understanding the mechanisms involved in biofilm formation may lead to the development of strategies for the control of some infections. The quorum-sensing system of cell-cell communication is one of the proposed mechanisms for the coordination of biofilm development (Coelho et al. 2011). In $S$. aureus, the agr is the best-characterized QS system. The agr locus is a complex multigenic system that responds to bacterial cell density, controlling the expression of adhesins and exoproteins of $S$. aureus. Thus, the expression of adhesins and surface proteins, such as protein A, are expressed in the initial stages whereas enzymes, immunotoxins, and cytotoxins are secreted later (Marques et al. 2013). The Agr system consists of four genes (agrA, $\operatorname{agr} \mathrm{C}, \operatorname{agr} \mathrm{D}$ and $\operatorname{agr\mathrm {B}}$ ) that are co-transcribed and organized into a trans-membrane transduction complex of two components (AgrA and AgrC), a pro-signaling peptide AgrD), and a membrane component (AgrB) responsible for the externalization of the modified signaling peptide. The signaling molecule also called the autoinducing peptide (AIP), is a peptide consisting of 7-9 amino acids. The effector molecule of the Agr system is a regulatory RNA, the RNAIII, whose synthesis is dependent on the activation of the Agr system and driven by the promoter of the Agr P3 system. RNAIII, a 514 nucleotide RNA molecule, regulates the expression of many genes encoding exoproteins and proteins associated with the cell wall of S. aureus. In addition to its regulatory function, RNAIII is the mRNA encoding the delta-toxin (Geisinger et al. 2012).

In $S$. aureus, there are four Agr groups characterized according to the difference in the amino acid sequence of AIP, and it has been observed that the activity of Agr within one group inhibits the activity of other groups. This phenomenon is known as "bacterial interference." Recent studies indicate that distinct Agr groups are associated with virulence and occurrence patterns in infested and specific geographic regions, which means a clonal distribution of Agr types (Montanaro et al. 2010).

In bacteria, the control of gene expression allows the cells to adjust to the nutritional changes in the environment so that their growth and division are optimized. Measuring gene expression is fundamental in many areas of research and, in this context, the real-time PCR technique (qPCR) has become a reference for quantification of nucleic acids (Bustin et al. 2009) and a powerful tool for quantification of gene expression (Schmittgen \& Livak 2008).

Given the importance of biofilm formation in the development of mastitis caused by S. aureus, the present work aimed to evaluate the expression and regulation of icaA, icaD and hld genes involved in its production, given the importance of increasing strategies for the treatment of related infections with biofilm production. The comprehension of this process could allow the development of effective measures of antibiofilm approaches that improve the treatment of biofilm-related infections (Savage et al. 2013).

\section{MATERIALS AND METHODS}

Sampling. A total of 120 milk samples were collected from three dairy farms located in the municipalities of Vassouras, Passa Três, and Barra do Piraí, in Rio de Janeiro, from October to November 2012. This study considered the profile of biofilm production of 20 Staphylococcus aureus according to Marques et al. (2013). The protocol of genotypic characterization of the genus Staphylococcus and the $S$. aureus species and the proteomic identification by Matrix Assisted Laser Ionization/Desorption Flight Time (MALDI-TOF) was performed as described by Motta et al. (2014). The S. aureus standard strain ATCC 29213 was used as a control.

Phenotypic detection of biofilm formation on microplates. The microplate biofilm formation was evaluated through the methodology described by Marques et al. (2013). All 20 isolates were inoculated on sheep blood agar (AS) for $24 \mathrm{~h}$ at $35^{\circ} \mathrm{C}$ and then colonies were transferred to $\mathrm{BHI}$ agar and incubated at $35^{\circ} \mathrm{C}$ for $24 \mathrm{~h}$. Bacterial cultures were adjusted to a scale of $0.5 \mathrm{McF}$ Farland and diluted 1:10 in TSA broth with the addition of $0.24 \%$ glucose. Two hundred $\mu \mathrm{L}$ aliquots of this suspension were inoculated into 96-well sterile polystyrene microplates and incubated for $24 \mathrm{~h}$ at $35^{\circ} \mathrm{C}$ without shaking. After incubation, this material was discarded, and the wells were washed twice with $200 \mu \mathrm{L}$ of sterile saline solution, oven dried 
at $65^{\circ} \mathrm{C}$ for $1 \mathrm{~h}$ and stained with $200 \mu \mathrm{L} 1 \%$ safranin for $15 \mathrm{~min}$. The wells were washed three times with distilled water and dried at room temperature. The absorbance was determined at $490 \mathrm{~nm}$ in ELISA reader (BIO-RAD MODEL 680). Uninoculated wells containing TSA broth with $0.24 \%$ glucose served as blank control. The tests were performed in triplicate. The intensity of biofilm formation was used to classify the strains according to the following OD values obtained: strong $\geq 0.3$; moderate $\geq 0.2$ and $<0.3$; weak $\geq 0.1$ and $<0.2$.

Detection of $\boldsymbol{S}$. aureus biofilm formation genes and Agr. In the present study, conventional PCR technique (CPCR) was used to amplify icaA, icaD (Vasudevan et al. 2003) and the exoprotein regulatory gene, agr (RNA III) (Reinoso 2004) involved in the production of EPS in all $S$. aureus isolates. For the Agr system typing, specific primers were used for each group based on the hypervariable domain of the agr locus, according to Shopsin et al. (2003). A sense oligoinitiator, pan-agr (5-ATGCACATGGTGCACATGC-3), corresponding to conserved sequences of the agrB gene, was used in all reactions. Four anti-sense primers, each specific for the amplification of a single agr group based on agr locus polymorphism were used as follows: agr I, 5-GTCACAAGTACTATAAGCTGCGAT-3; agr II, 5-GTATTACTAATTGAAAAGTGCCATAGC-3; $a g r$ III, 5-CTGTTGAAAAAGTCAACTAAAAGCTC-3; and agrIV,5-CGATAATGCCGTAATAC CCG-3. Duplex PCR was performed to identify agr I (440 bp) and $a g r$ II (572 bp) and agr III (406 bp) and agr IV (588 bp) types.

Two (2) strains, N-353 and N-361, were chosen randomly for sequencing of the agr II gene. PCR products were purified using Exo-Sap (USB Corporation, Cleveland/Ohio), as recommended by the manufacturer, and then subjected to sequencing on the Genetic Analyzer ABI 3130xl (Applied Biosystems, Perkin Elmer, CA, USA) (Sanger et al. 1977). The quality of the spherograms and the contigs were evaluated using the Bioedit program (Hall 1999). The agr II gene sequences obtained in this study were compared with other sequences deposited in the NCBI database ${ }^{3}$ using the BLAST algorithm (Altschul et al. 1997).

Selection of biofilm-forming $\boldsymbol{S}$, aureus samples. For this purpose, the $\mathrm{N}-354($ icaA $+/$ icaD $+/$ bap $+/$ agr +$), \mathrm{N}-365($ icaA + / $i c a \mathrm{D}+/$ bap $-/ a g r+)$ and $\mathrm{N}-341($ ica $+/$ ica $+/$ bap $+/ a g r+)$ isolates formation of weak, moderate and strong biofilms, respectively. The strains underwent two successive inoculations in Blood Agar to reactivate their biofilm formation properties, and after that, they were streaked on BHIA for $24 \mathrm{~h}$ at $35^{\circ} \mathrm{C}$. Colonies grown in BHIA were adjusted to the scale of $0.5 \mathrm{McF}$ arland and diluted 1:10 in CTSA plus $0.24 \%$ glucose. The bacterial growth tubes were adjusted to a final volume of $10 \mathrm{~mL}$ and incubated statically at $35^{\circ} \mathrm{C}$ for 4,8 , 12 and $24 \mathrm{~h}$. After incubation, the tubes were washed twice with diethylpyrocarbonate water $(0.1 \%$ DEPC) to remove all planktonic cells. The adherent cells were resuspended with $0.1 \%$ DEPC water by scraping until the visible cell layer detached from the bottom of the tube. The suspensions were incubated with two times their volume of RNA Protect Bacteria (Qiagen ${ }^{\circledR}$ ), vortexed for 5 seconds, incubated for $5 \mathrm{~min}$ an approximated temperature of $21^{\circ} \mathrm{C}$. The mixture was pelleted by centrifugation at $10,000 \mathrm{x}$ g for $10 \mathrm{~min}$, and the pellets were stored at $-80^{\circ} \mathrm{C}$ until extraction of the RNA.

Extraction and quantification of total RNA. RNeasy Protect Bacteria Mini Kit (Qiagen ${ }^{\circledR}$ ) was used for RNA extraction according to the manufacturer's instructions. The elimination of DNA traits present in the total RNA was performed using the RQ1 RNase-Free DNase kit (Promega ${ }^{\circledR}$ ). To confirm the absence of gDNA in total RNA samples extracted, a PCR reaction of 16S rRNA gene (Atshan et al. 2013) was performed using similar conditions of qPCR. RNA

3 GenBank. Available at <http://www.ncbi.nlm.nih.gov/> quantification was done by fluorimetry using okit Qubit ${ }^{\mathrm{TM}}$ RNA BR Assay on QUBIT $^{\circledR} 2.0$ Fluorometer (Thermo Fisher Scientific, Wilmington/DE, USA). The integrity of the RNA was analyzed by $1 \%$ agarose gel electrophoresis in $1 \mathrm{X}$ MOPS buffer stained with ethidium bromide and observed under ultraviolet light by the L-PIX EX (Loccus Biotechnology) image capture system.

Reverse Transcription Reaction for cDNA Synthesis. The cDNA synthesis was performed using the AMV Reverse Transcriptase A3500 kit (Promega) from $1 \mu \mathrm{g}$ of total RNA plus $1 \mathrm{mM} \mathrm{dNTP,} 5 \mathrm{mM} \mathrm{MgCl}$ 2, 0.5 $\mu \mathrm{g}$ Random Primers, 20U Recombinant RNasin, 15U of AMV Reverse Transcriptase and RT Buffer 1x. Samples were incubated at room temperature for $10 \mathrm{~min}, 42^{\circ} \mathrm{C}$ for $15 \mathrm{~min}, 95^{\circ} \mathrm{C}$ for $5 \mathrm{~min}$ and at $5^{\circ} \mathrm{C}$ for $5 \mathrm{~min}$ for cDNA synthesis. Quantification of cDNA was performed by fluorimetry using the Qubit ${ }^{\mathrm{TM}}$ ssDNA Assay kit on QUBIT ${ }^{\circledR} 2.0$ Fluorometer (Thermo Fisher Scientific, Wilmington/ DE, USA). After this, the cDNA was diluted with RNase-free water and stored at $-20^{\circ} \mathrm{C}$ until use.

Design and selection of primers. The primers used for the analysis of the hld gene expression were designed using Primer Express 3.0 software based on a sequence of the $S$. aureus gene available from GenBank (DQ157979.1). Concentrations of $200 \mathrm{nM}, 400 \mathrm{nM}, 600 \mathrm{nM}$ and $900 \mathrm{nM}$ of the primers were tested to optimize the qPCR assays. Optimum concentrations were considered the lowest concentrations that obtained the lowest $\mathrm{Cq}$ (quantification cycle) and the maximum $\Delta \mathrm{Rn}$ (Normalized Reporter) in the absence of dimers. The primers already described in the literature for icaA (151 bp) 5-GAGGTAAAGCCAACGCACTC-3 and CCTGTAACCGCACCAAGTTT (Atshan et al. 2013); icaD (211 bp) 5ACCCAACGCTAAAATCATCG-3 and 5- GCGAAAATGCCCATAGTTTC-3 (Atshan et al. 2013); gyrB (242 bp) 5- GTCGAAGGGGACTCTG-3 and 5- GCTCCATCCACATCGG-3 (Sihto et al. 2014); 16S rRNA (191 bp) 5GGGACCCGCACAAGCGGTGG-3 and 5- GGGTTGCGCTCGTTGCGGGA-3 (Atshan et al. 2013), and the primers developed in this study to amplify the hld gene (74 pb) 5-TTCACTGTGTCGATAATCCATTTTACT-3 and 5-GGAGTGATTTCAATGGCACAAG-3 were used in this investigation. The characteristics of all primers were tested using Oligo Analyze 1.0.2 software, and the specificity was first tested in silico by the Primer-BLAST tool ${ }^{4}$.

qPCR reactions. The $\mathrm{qPCR}$ reactions were carried out in a final volume of $20 \mu \mathrm{L}$ containing: $1 \mathrm{X}$ of the Power SYBR ${ }^{\circledR}$ Green PCR Master Mix (Applied Biosystems), 0.9/0.9 $\mu \mathrm{M}$ of the primers for the icaA, icaD, hld and gyrB genes and $0.4 / 0.4 \mathrm{uM}$ for the $16 \mathrm{~S}$ rRNA gene and 20ng cDNA. The assays were performed in triplicate in the Step One Plus ${ }^{\mathrm{TM}}$ Real-Time PCR System (Applied Biosystems). Thermocycling conditions were: $95^{\circ} \mathrm{C}$ for 5 minutes, and 40 cycles of $95^{\circ} \mathrm{C}$ for 20 seconds, $60^{\circ} \mathrm{C}$ for 20 seconds, and $72^{\circ} \mathrm{C}$ for 20 seconds. At the end of the 40 cycles, a dissociation curve of the amplicons was added to verify the amplification specificity. All experiments and reactions were performed according to the MIQE proposed by Bustin et al. (2009).

Analysis of the efficiency of the qPCR reactions for the icaA, icaD, hld, gyrB and 16S rRNA. Standard curves for each gene were constructed from a standard $S$. aureus cDNA at the concentration of $20 \mathrm{ng} / \mu \mathrm{L}$ to determine the effectiveness of target gene and reference genes amplification assays. From this concentration, serial decimal dilutions were performed up to the concentration of $2 \times 10^{-4} \mathrm{ng} / \mu \mathrm{l}$, comprising five points in the curve. The qPCR reactions were performed in triplicate for each point of the curve. The results were used to evaluate the linearity and the analytical sensitivity of the qPCR protocol through

\footnotetext{
4 Available at <http://www.ncbi.nlm.nih.gov/tools/primer-blast/ index. cgi? LINK_LOC = BlastHome>
} 
a standard curve. Linearity was determined by plotting the Cq value with the cDNA concentration at each point of the curve using SigmaPlot ${ }^{\circledR}$ software version 10.0 (Systat Software Inc, San Jose/CA, USA). The linear regression, along with the determination coefficient (R2) formed after the determination of each point of the curve, was used to evaluate if the qPCR test was optimized. The efficiency of the reaction was determined considering the inclination of the standard curve using the following formula: [Efficiency = 10 (-1 / slope) - 1] (Svec et al. 2015).

Analysis of gene expression. Five genes were analyzed, three targets (icaA, icaD and $h l d$ ) and two reference (gyrB and 16S rRNA) (Atshan et al. 2013, Sihto et al. 2014). For gene expression the comparative method of $\mathrm{Cq}(\Delta \Delta \mathrm{Cq})$ (Livak \& Schmittgen 2001) was used. The $\mathrm{N}-354($ ica $+/ i c a \mathrm{D}+/$ bap $-/ a g r+), \mathrm{N}-365($ icaA $+/$ icaD + / bap -/agr +) and $\mathrm{N}-341($ icaA $+/ i c a \mathrm{D}+/$ bap $+/ a g r+)$ isolates were submitted to growth times of 4, 8, 12 and 24 hours. The 4 hours interval was considered the calibrator treatment. The X-fold change of the transcription level was calculated by the comparative method of Cq $(\Delta \Delta \mathrm{Cq})$ (Livak \& Schmittgen 2001). For each experimental sample, standard curves were generated for both, target and reference (16S rRNA). The data were analyzed using the SigmaPlot ${ }^{\circledR}$ software version 10.0 (Systat Software Inc, San Jose/CA, USA). The calculation of the gene expression was determined by the formula 2- $\Delta \Delta \mathrm{Cq}$, where: $\Delta \Delta \mathrm{Cq}=\Delta \mathrm{Cq}$ (target) $-\Delta \mathrm{Cq}$ (calibrator). The qPCR reactions were performed in triplicate.

\section{RESULTS}

\section{Pheno and genotypic biofilm production profile}

All 20 Staphylococcus aureus were biofilm producers comprising 55\% (11/20) strong producers, 30\% (6/20) moderate producers and $15 \%(3 / 20)$ weak producers. In this study, 17 isolates (85\%) were positive for the icaA gene, $19(95 \%)$ were positive for the icaD gene, $16(80 \%)$ for both genes, and only one (5\%) was positive for the bap gene. All biofilm producers had at least one of these genes; however, it was not observed any correlation between pheno and genotypic biofilm production patterns. Two weakly biofilm producer isolates were positive for both genes.

\section{Distribution of agr (RNAIII) genes and Agr system types in $S$. aureus isolates}

All S. aureus isolates were positive for the agr RNAIII gene, an intracellular effector of the quorum sensing system in this species. The Agr system is divided into four major groups based on the amino acid sequence polymorphism of the AIP and its corresponding receptor (AgrC). In this study, Agr type II group presented a prevalence of $70 \%(14 / 20)$, while $30 \%$ $(6 / 20)$ were not typable. Two strains (N-353 and N-361) were sequenced using BLASTn and yielded a $96 \%$ and $97 \%$ identity, respectively, to the Staphylococcus aureus AK15Y-Type II Agr sequence (GenBank JX398934.1) and e-value equal to 0.0 for both. The sequencing results confirmed that these strains are Agr-type II.

\section{Stability of RNA, cDNA and specificity and analysis of the efficiency of the qPCR reactions for the icaA, icaD, hld, gyrB and 16S rRNA}

The quality and quantity of RNA extracted at different growth time ( $4 \mathrm{~h}, 8 \mathrm{~h}, 12 \mathrm{~h}$ and $24 \mathrm{~h})$ was satisfactory. The cDNA synthesis generated adequate amounts of product. All primers used at this study presented high specificity, generating a single product. The gyrB and 16S rRNA genes were evaluated to be used as reference genes. The 16S rRNA gene did not show Cq variation at the tested conditions, being selected as reference gene.

Analyses of the standard curve in relation to efficiency $(\varepsilon)$, correlation coefficient $\left(\mathrm{R}^{2}\right)$ and slope demonstrated that the system performance for target detection was ideal. The efficiency of real-time PCR was calculated and the standard curves of the genes target and 16S rRNA reference gene showed similar results of efficiency (icaA gene revealed $\varepsilon=$ $107.78 \%, \mathrm{R}^{2}=0.9958$; $i c a \mathrm{D}$ gene revealed $\varepsilon=111.69 \%, \mathrm{R}^{2}=$ 0.9883 ; hld gene revealed $\varepsilon=104.64 \%, \mathrm{R}^{2}=0.9985 ; 16 \mathrm{~S}$ rRNA revealed $\varepsilon=100.58 \%, R^{2}=0.9981$ ), which enabled the relative quantification through the comparative method $2-\Delta \Delta$ Cq.

\section{Analysis of icaA, icaD and hld gene expression during biofilm formation in $S$. aureus isolates}

The analysis of the transcriptional expression of the weak biofilm-producer $\mathrm{N}$-354 strain showed that the relative mRNA expression of the icaD gene reached its peak in eight hours being 1.28 times higher than the calibrator. The peak was reached for the icaA gene at four hours. In 24 hours, the expression of both ica genes decreased, whereas the hld gene increases to achieve the highest level of expression, 1.25 times greater than the calibrator (Fig.1). Also, the relative mRNA expression peak of the icaA and icaD genes of the strong biofilm-producer N-341 strain was higher in eight hours growth time, with relative mRNA expression of 4.17

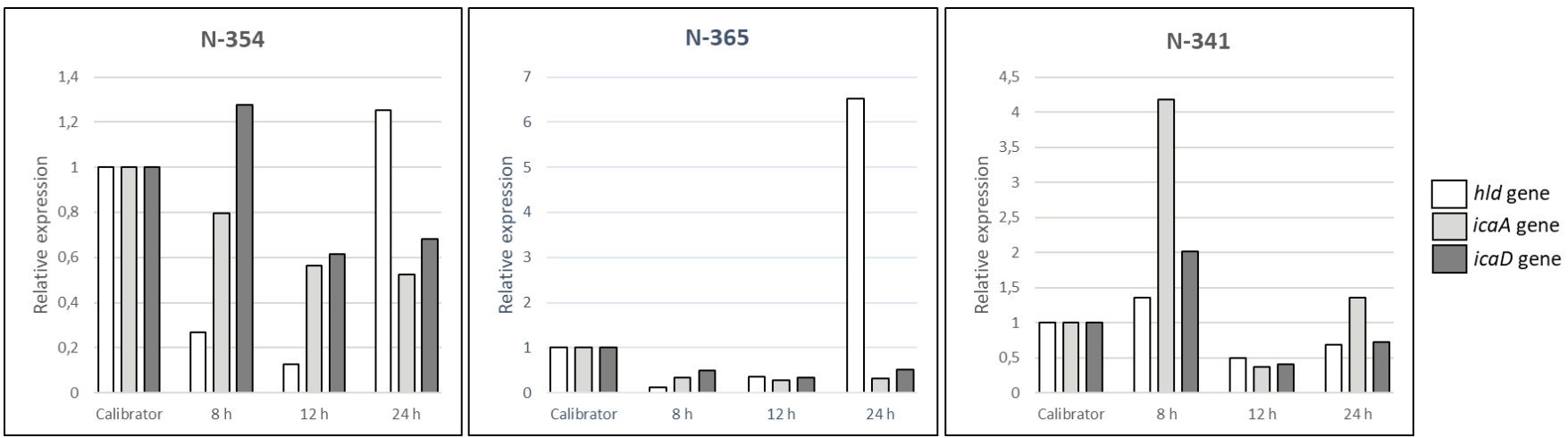

Fig.1. Results comparison of expression of biofilm-producer strains: relative mRNA expression of the hld, icaA and icaD genes of the weak, moderate, and strong biofilm-producer Staphylococcus aureus, N-354, N-365 and N-341 strains, respectively. Calibrator = sample represent the treatment with 4 hours of growth, where no biofilm formation was observed. 
and 2.01, respectively. Its levels of icaA and icaD expression were higher than those achieved by the N-354 strain. The hld gene presented a relative mRNA expression of $1.35 ; 0.5$ and 0.69 at times of 8, 12 and 24 h, respectively. Expression of the hld gene was higher in eight hours, decreased in $12 \mathrm{~h}$, rising again in $24 \mathrm{~h}$. The expression of the hld gene is likely to reach its peak at a time after the maximum time evaluated in this experiment (Fig.1). Regarding the moderate biofilmproducer N-365 strain it was observed the lowest expression of the icaA and icaD genes. However, the expression of hld gene was 6.51 times bigger than the calibrator in 24h (Fig.1).

\section{DISCUSSION}

The ability of biofilm formation guarantees bacterial adhesion and maintenance in the mammary gland tissue, so a better understanding of this characteristic provides subsidies for more effective treatment measures in bovine mastitis (Melchior et al. 2009). In this study, all Staphylococcus aureus biofilm producers presented at least one of these genes; however, it was not observed any correlation between pheno and genotypic biofilm production patterns. Singh et al. (2013) also detected 98\% staphylococci isolates able to produce biofilm whereas just 77.9\% and $75.7 \%$ presented icaA and ica $\mathrm{D}$ genes, respectively. A recent study, developed by Salina et al. (2020), there was no association between the presence of icaAD genes and biofilm formation, confirming that this correlation is not clear, and needs to be better understand.

The low incidence of the bap gene, at the present study, predicts that the ica-dependent mechanism, producer of PIA, is the main responsible for the adhesion and biofilm formation in the studied strains. Otherwise, the only isolate presenting the bap gene in this study $(\mathrm{N}-341)$ is a strong biofilm producer. Tormo et al. (2005) observed that all staphylococci isolates harboring the bap gene are strong biofilm producers, even though most do not have the icaADBC operon. These authors concluded that the Bap protein can mediate an alternative mechanism to the PIA/PNAG. Bap promotes both initial adhesions to abiotic surfaces and intercellular aggregation, ensuring their participation in the biofilm formation process in $S$. aureus.

The molecule RNAIII is not essential for the growth of $S$. aureus in vitro but modulates the expression of genes involved in its pathogenesis although its function in biofilm formation remains unknown. Boles \& Horswill (2008) have shown that repression of the agr system is necessary for the establishment of biofilm and that reactivation of agr in established biofilms through the addition of AIP or glucose depletion causes its dispersion. At the present study, all isolates presented RNAIII, demonstrating that this is an important quorum-sensing system for specific strains.

In this study, Agr type II group was prevalent. The high prevalence of the Agr type II group has also been observed by other authors (Melchior et al. 2009, Fabres-Klein at al. 2015). Fabres-Klein et al. (2015) observed that strains of $S$. aureus isolated from bovine milk presented high biofilm production to adapt to the milk-filled environment found in the udder. So the Agr system has been characterized as a central part of the development of staphylococcal mastitis pathogenesis since its deactivation allows $S$. aureus adheres to surfaces and forms biofilm, otherwise when the Agr system is activated, in the post-exponential and stationary stages of growth, cells can detach from the biofilm and return to the planktonic state (Thoendel et al. 2011).

Studies on the gene expression related to the biofilm formation in S. aureus are still limited (Atshan et al. 2013). Also, the mechanisms involved in the expression of binding proteins and EPS and their influence on staphylococci biofilms must be clarified (Atkin et al. 2014). The transcriptional expression of the icaA and icaD genes by the N-354 and N-341 strains confirms that the production of the polysaccharide mediated by the icaADBC operon genes is an important mechanism related to the capacity of adhesion and biofilms formation and contributes to the early stages of bacterial growth. Yibao Ma et al. (2012) detected an 88\% increase in the icaA expression during the logarithmic phase of growth and $40 \%$ reduction in the stationary phase suggesting the ica genes are associated with the initial colonization but not with staphylococci persistence. In this study, the stronger biofilm producer (N-341) had the transcription of both genes (icaA and ica $\mathrm{D}$ ) increased compared to the weaker biofilm producer (N-354). For the N-341 strain, the icaA gene expression was critical for the initial cell aggregation whereas the icaD gene played a more crucial role for the N-354 strain along the growth curve. Otherwise, considering that N-365 strain is phenotypically biofilm producer but presented low rates of icaA and icaD genes expression, a possible hypothesis is that biofilm formation occurs through the production of proteins that facilitate cell-cell aggregation, rather than the exopolysaccharide investigated. Since the adhesion step is of importance within the establishment of the infectious process, it is plausible that the microorganism develops different pathways to produce adhesins. It had already been proven that the surface protein of S. aureus, SasG, as well as its homologue in Staphylococcus epidermidis, Aap, can mediate the intercellular interactions and development of the biofilm in the absence of the operon ica (Formosa-Dague et al. 2016).

The hld gene in addition to encoding the delta-toxin is also the effector molecule of the Agr regulatory system (Geisinger et al. 2012). Agr system is the active the RNA III molecule is produced by positively regulating the expression of genes encoding exotoxins and proteases and negatively regulating the proteins associated with the cell wall of $S$. aureus. Studies have shown that strains of $S$. aureus with the inactivated locus formed thicker biofilms when compared to wild strains (Tan et al. 2015). The Agr system controls the production of enzymes that degrade the biofilm matrix. Activation of the Agr system is associated with inhibition of biofilm maturation. The reactivation of Agr in already formed biofilms results in the detachment of mature biofilm cells (Boles \& Horswill 2011).

The high expression of hld of the N-365 strain in the stationary phase seems to be necessary to activate the synthesis of extracellular proteases required for the lack of biofilm of protein nature, as proposed by Boles \& Horswill (2008). In S. aureus, the Agr system controls the expression of at least ten extracellular proteases, which may mediate biofilm dispersion (Thoendel et al. 2011). Martí et al. (2010) developed a work where they verified that it has a positive effect on the expression of proteases during the stationary phase and that these proteases control the formation of the biofilm and may even inhibit its formation. It is important to note that these results are limited to a single strain, and it is certainly possible that $\mathrm{N}-365$ has an alternative means to 
promote intercellular accumulation that alleviates the need for PIA. However, further studies are needed to verify whether this biofilm is of protein origin and whether other binding factors would be helpful in the accumulation of biofilm cells at different time points of bacterial growth.

\section{CONCLUSIONS}

Transcriptional expression showed that icaA gene seemed more relevant for the initial cell aggregation in strong biofilm-producer ( $\mathrm{N}-341$ ) strain whereas icaD gene played a more critical role for weak biofilm-producer (N-354) strain, confirming that polysaccharides production mediated by the icaADBC operon genes is an essential mechanism to the biofilm formation and contributes to the early stages of bacterial growth.

A different biofilm expression profile was observed regarding the moderate biofilm-producer (N-365) strain with the lowest expression of the icaA and icaD genes. A possible explanation is that biofilm formation occurs through the production of proteins that facilitate cell-cell aggregation rather than the production of the investigated exopolysaccharide. So further studies must be carried on to better understand this aspect.

As far as we know, this is the first study to show the difference in transcriptional expression of icaA and icaD genes among strains with distinct biofilm production profile.

Acknowledgments.- The "Conselho Nacional de Desenvolvimento Científico e Tecnológico" (CNPq, Rio de Janeiro, Brazil, process 308528/2011-5), "Fundação de Amparo à Pesquisa do Estado do Rio de Janeiro" (FAPERJ, process E-26/112.658/2012) and "Coordenação de Aperfeiçoamento de Pessoal de Nível Superior" (CAPES) supported this study.

Conflicts of interest statement.- The authors declare no conflicts of interest.

\section{REFERENCES}

Altschul S.F., Madden T.L., Schaffer A.A., Zhang J., Zhang Z., Miller W. \& Lipman D.J. 1997. Gapped BLAST and PSI-BLAST: a new generation of protein database search programs. Nucleic Acids Res. 25(17):3389-3402. <https://dx.doi.org/10.1093/nar/25.17.3389> <PMid:9254694>

Arciola C.R., Campoccia D., Speziale P., Montanaro L. \& Costerton J.W. 2012. Biofilm formation in Staphylococcus implant infections. A review of molecular mechanisms and implications for biofilm-resistant materials. Biomaterials 33(26):5967-5982.<https://dx.doi.org/10.1016/j.biomaterials.2012.05.031> $<$ PMid:22695065>

Atkin K.E., Macdonald S.J., Brentnall A.S., Potts J.R. \& Thomas G.H. 2014. A different path: revealing the function of staphylococcal proteins in biofilm formation. FEBS Letters 588(10):1869-1872.<https://dx.doi.org/10.1016/j. febslet.2014.04.002><PMid:24735724>

Atshan S.S., Shamsudin M.N., Karunanidhi A., Belkum A., Lung L.T.T., Sekawi Z., Nathan J.J., Ling K.H., Seng J.S.C., Ali A.M., Abduljaleel S.A. \& Hamat R.A. 2013. Quantitative PCR analysis of genes expressed during biofilm development of methicillin resistant Staphylococcus aureus (MRSA). Infect. Genet. Evol. 18:106-112. <https://dx.doi.org/10.1016/j.meegid.2013.05.002> $<$ PMid:23669446>

Boles B.R. \& Horswill A.R. 2008. agr-mediated dispersal of Staphylococcus aureus biofilms. PLoS Pathog. 4(4):e1000052.<https://dx.doi.org/10.1371/ journal.ppat.1000052 ><PMid:18437240>

Boles B.R. \& Horswill A.R. 2011. Staphylococcal biofilm disassembly. Trends Microbiol.19(9):449-455. <https://dx.doi.org/10.1016/j.tim.2011.06.004> $<$ PMid:21784640>
Bustin S.A., Benes V., Garson J.A., Hellemans J., Huggett J., Kubista M., Mueller R., Nolan T., Pfall M.W., Shipley G.L., Vandesompele J. \& Wittwer C.T. 2009. The MIQE guidelines minimum information for publication of quantitative real-time PCR experiments. Clin. Chem. 55(4):611-622. <https://dx.doi. org/10.1373/clinchem.2008.112797> <PMid:19246619>

Coelho S.M.O., Pereira I.A., Soares L.C., Pribul B.R. \& Souza M.M.S. 2011. Profile of virulence factors of Staphylococcus aureus isolated from subclinical bovine mastitis in the state of Rio de Janeiro, Brazil. J. Dairy Sci. 94(7):3305-3310. <https://dx.doi.org/10.3168/jds.2010-3229> <PMid:21700015>

Fabres-Klein M.H., Santos M.J.C., Klein R.C., Souza G.N. \& Ribon A.O.B. 2015. An association between milk and slime increases biofilm production by bovine Staphylococcus aureus. BMC Vet. Res. 11(3). <https://dx.doi. org/10.1186/s12917-015-0319-7><PMid:25591667>

Formosa-Dague C., Spezialeb P., Fosterc T.J., Geogheganc J.A. \& Dufrênea Y.F. 2016. Zinc-dependent mechanical properties of Staphylococcus aureus biofilm-forming surface protein SasG. PNAS 113(2):2410-2415. <https:// dx.doi.org/10.1073/pnas.1519265113>

Geisinger E., Chen J. \& Novick R.P. 2012. Allele-dependent differences in Quorum-Sensing dynamics result in variant expression of virulence genes in Staphylococcus aureus. J. Bacteriol. 194(11):2854-2864. <https://dx.doi. org/10.1128/JB.06685-11>

Hall T.A. 1999. BioEdit: a user-friendly biological sequence alignment editor and analysis program for Windows 95/98/NT. Nucl. Acids Symp. Ser. 41:95-98.

Livak K.J. \& Schmittgen T.D. 2001. Analysis of relative gene expression data using real time quantitative PCR and the $2^{-\Delta \Delta c t}$ method. Methods 25(4):402408. <https://dx.doi.org/10.1006/meth.2001.1262><PMid:11846609>

Marques V.F., Souza M.M.S., Mendonça E.C.L., Alencar T.A., Pribul B.R., Coelho S.M.O., Lasagno M. \& Reinoso E.B. 2013. Análise fenotípica e genotípica da virulência em Staphylococcus spp. e de sua dispersão clonal como contribuição ao estudo da mastite bovina em regiões do Estado do Rio de Janeiro. Pesq. Vet. Bras. 33(2):161-170. <https://dx.doi.org/10.1590/ S0100-736X2013000200005>

Martí M., Trotonda M.P., Tormo-Más M.A., Vergara-Irigaray M., Cheung A.L., Lasa I.L \& Penadés J.R. 2010. Extracellular proteases inhibit protein-dependent biofilm formation in Staphylococcus aureus. Microbes Infect. 12(1):55-64. <https://dx.doi.org/10.1016/j.micinf.2009.10.005> <PMid:19883788>

Melchior M.B., Van Osch M.H.J., Graat R.M., Van Duijkeren E., Mevius D.J., Nielen M., Gaastra W. \& Fink-Gremmels J. 2009. Biofilm formation and genotyping of Staphylococcus aureus bovine mastitis isolates: evidence for lack of penicillin-resistance in Agr-type II strains. Vet. Microbiol. 137(1/2):83-89. <https://dx.doi.org/10.1016/j.vetmic.2008.12.004> <PMid:19150182>

Montanaro L., Speziale P., Campoccia D., Pirini V., Ravaioli S., Cangini I., Visai L. \& Arciola C.R. 2010. Polymorphisms of agr locus correspond to distinct genetic patterns of virulence in Staphylococcus aureus clinical isolates from orthopedic implant infections. J. Biomed. Mater. Res. A 94(3):825-832. <https://dx.doi.org/10.1002/jbm.a.32764> <PMid:20336749>

Motta C.C., Rojas A.C.M., Dubenczuk F.C., Botelho L.A.B., Moreira B.M., Coelho S.M.O., Coelho I.S. \& Souza M.M.S. 2014. Verification of molecular characterization of coagulase positive Staphylococcus from bovine mastitis with matrix-assisted laser desorption ionization, time-offlight mass spectrometry (MALDI-TOF MS) mass spectrometry. Afr. J. Microbiol. Res. 8(48):3861-3866.

Reinoso E.B. 2004. Análisis epidemiológico y molecular de cepas de Staphylococcus aureus de distintos Orígenes. Doctoral Dissertation, Universidade Nacional de Rio Cuarto, Rio Cuarto. 199p.

Saei H.D. 2012. coa types and antimicrobial resistance profile of Staphylococcus aureus isolates from cases of bovine mastitis. Comp. Clin. Pathol. 21(3):301-307. <https://dx.doi.org/10.1007/s00580-010-1096-0>

Salina A., Guimarães F.F., Richini Pereira V.B., Menozzi B.D., Raul V.L.M. \& Langoni H. 2020. Detection of icaA, icaD, and bap genes and biofilm production in Staphylococcus aureus and non-aureus staphylococci isolated from subclinical and clinical bovine mastites. Arq. Bras. Med. Vet. Zootec. 72(3):1034-1038. <https://dx.doi.org/10.1590/1678-4162-11284> 
Sanger F., Nicklen S. \& Coulson A.R. 1977. DNA sequencing with chainterminating inhibitors. PNAS 74(12):5463-5467. <https://dx.doi. org/10.1073/pnas.74.12.5463><PMid:271968>

Savage V.J., Chopra I. \& O’Neill A.J. 2013. Staphylococcus aureus biofilms promote horizontal transfer of antibiotic resistance. J. Antimicrob. Antichem. Agents 57(4):1968-1970. <https://dx.doi.org/10.1128/AAC.02008-12> <PMid:23357771>

Schmittgen T. \& Livak K. 2008. Analyzing real-time PCR data by the comparative CT method. Nat. Protocols 3(6):1101-1108. <https://dx.doi.org/10.1038/ nprot.2008.73><PMid:18546601>

Shopsin B., Mathema B., Alcabes P., Said-Salim B., Lina G., Matsuka A., Martinez J. \& Kreiswirth B.N. 2003. Prevalence of agr Specificity Groups among Staphylococcus aureus strains colonizing children and their guardians. J. Clin. Microbiol. 41(1):456-459. <https://dx.doi.org/10.1128/jcm.41.1.456459.2003><PMid:12517893>

Sihto H.M., Tasara T., Stephan R. \& Johler S. 2014. Validation of reference genes for normalization of qPCR mRNA expression levels in Staphylococcus aureus exposed to osmotic and lactic acid stress conditions encountered during food production and preservation. FEMS Microbiol. Lett. 356(1):134-140. <https://dx.doi.org/10.1111/1574-6968.12491><PMid:24893820>

Singh A., Walker M., Rousseau J. \& Weese J.S. 2013. Characterization of the biofilm forming ability of Staphylococcus pseudintermedius from dogs. BMC Vet. Res. 9(93). <https://dx.doi.org/10.1186/1746-6148-9-93> <PMid:23641755>
Svec D., Tichopad A., Novosadova V., Pfaff M.W. \& Kubista M. 2015. How good is a PCR efficiency estimate: Recommendations for precise and robust qPCR efficiency assessments. Biomol. Detect. Quantif. 3:9-16. <https://dx.doi.org/10.1016/j.bdq.2015.01.005> <PMid:27077029>

Tan X., Qin N., Wu C., Sheng J., Yang R., Zheng B., Ma J., Liu L., Peng X. \& Jia A. 2015. Transcriptome analysis of the biofilm formed by methicillin susceptible Staphylococcus aureus. Sci. Rep. 5(1):11997. <https://dx.doi. org/10.1038/srep11997><PMid:26149474>

Thoendel M., Kavanaugh J.S., Flack C.E. \& Horswill A.R. 2011. Peptide signaling in the Staphylococci. Chem. Rev. 111(1):117-151.<https://dx.doi.org/10.1021/ cr100370n $><$ PMid:21174435>

Tormo M.A., Knecht E., Götz F., Lasa I. \& Penadés J.R. 2005. Bap dependent biofilm formation by pathogenic species of Staphylococcus: evidence of horizontal gene transfer? Microbiol. 151(Pt 7):2465-2475. <https://dx.doi. org/10.1099/mic.0.27865-0><PMid:16000737>

Vasudevan P., Nair M.K.M., Annamalai T. \& Venkitanarayana K.S. 2003. Phenotypic and Genotipic characterization of bovine mastitis isolates os Staphylococcus aureus for biofilm formation. Vet. Microbiol. 92(1/2):179-185. <https://dx.doi.org/10.1016/s0378-1135(02)00360-7><PMid:12488081>

Yibao M., Yuanxi X., Yestrepsky B.D., Sorenson R.J., Chen M., Larsen S.D. \& Sun H. 2012. Novel inhibitors of Staphylococcus aureus virulence gene expression and biofilm formation. PLoS One 7(10):e47255.<https://dx.doi. org/10.1371/journal.pone.0047255><PMid:23077578> 